\title{
PENDIDIKAN, STATUS KERJA IBU TERHADAP FREKUENSI MELAKUKAN PIJAT BAYI TAHUN 2018
}

\author{
Yovita Erin Sastrini \\ Program Studi Diploma III Keperawatan STIKES Dirgahayu Samarinda \\ Jalan Pasundan No.21 Telp (0541) 748335, Fax. (0541)748335 \\ yovitaerin9@gmail.com
}

\begin{abstract}
ABSTRAK
Stimulasi pijat bayi menjadi salah satu upaya pelayanan kesehatan yang berkualitas dan terjangkau untuk membantu mengurangi angka kematian bayi. Pemijatan bayi adalah salah satu tugas domestik seorang ibu dalam rumah tangganya. Status pendidikan dan pekerjaan seorang ibu dapat menjadi faktor yang diperhitungkan dalam melakukan tugas domestiknya. Metode analisis data menggunakan teknik statistik deskriptif dan statistik inferensial. Uji signifikansi pengaruh tingkat pendidikan terhadap frekuensi pijat bayi dilakukan menggunakan teknik statistik analisis varians 1-jalur dan uji signifikansi pengaruh status kerja terhadap frekuensi pijat bayi dilakukan menggunakan teknik statistik $t$-student sampel saling bebas. Hasil: analisis varians memberikan hasil bahwa rata-rata frekuensi pijat bayi antara kelima kategori tingkat pendidikan tidak berbeda secara signifikan, sehingga disimpulkan bahwa tingkat pendidikan ibu tidak berpengaruh terhadap frekuensi melakukan pijat bayi. Analisis assosiatif antara variabel status kerja dengan frekuensi pijat bayi ditemukan kenyataan bahwa keterlibatan ibu sebagai angkatan kerja berpengaruh negatif terhadap frekuensi melakukan pijat bayi. Analisis statistik $t$-student sampel saling bebas untuk uji perbedaan rata-rata memberikan hasil bahwa ibu yang tidak bekerja lebih sering melakukan pijat bayi dibandingkan ibu yang bekerja dengan perbedaan 1.15 poin. Kesimpulan: 1) terdapat perbedaan status pekerjaan ibu terhadap frekuensi melakukan pijat bayi, 2) tidak ada perbedaan antara pendidikan terhadap frekuensi ibu melakukan pijat bayi. Rekomendasi: Penyuluhan/pemberian informasi dan pelatihan kepada masyarakat luas hendaknya digalakkan tanpa memandang pendidikan ibu dengan melibatkan pihak swasta serta didukung oleh pemerintah.
\end{abstract}

\section{Kata Kunci : Pendidikan, Status kerja, Frekuensi, pijat bayi}

\begin{abstract}
ABSCTRACT
Baby massage stimulation is one of the efforts of quality and affordable health services to help reduce infant mortality. Baby massage is a mother's domestic duties in caring for her baby. Education level and work status' mother could be a factor in carrying out her domestic duties. This study used descriptive statistical techniques and inferential statistics as the data analysis method. Significance test of the effect of education level on the frequency of baby massage was performed using a 1-path variance statistical analysis technique. Significance test of the effect of work status on the frequency of baby massage was carried out using a statistical t-student sample of each other independently. Results: analysis of variance showed that the average frequency of baby massage between the five categories of the education level was not significantly different. It was concluded that the mother's education level had no effect on the frequency of doing baby massage. Associative analysis between work status variables and frequency of baby massage found that maternal involvement in the labour level force negatively affected the frequency for doing baby massage. Statistical analysis of the t-student sample is independent of each other for the average difference test found that mothers who do not work massage babies more often than mothers who work with 1.15 points difference. Conclusion: 1) there is a difference in the mother's work status to the frequency of doing baby massage 2) there is no difference between the education levels of the frequency of mother doing baby massage. Recommendations: Counseling / providing information and training to the wider community should be encouraged regardless of maternal education by involving the private sector and supported by the government.
\end{abstract}

Keyword: Education level, work status, frequency, baby massage 


\section{PENDAHULUAN}

Salah satu indikator derajat kesehatan dan kemajuan suatu bangsa dan negara adalah Angka Kematian Bayi (AKB). Data Biro Pusat Statistik 2016 mencatat bahwa Angka kematian bayi (AKB) mencapai 25,5 kematian setiap 1.000 bayi yang lahir. Di kota Samarinda Provinsi Kalimantan Timur, jumlah kematian bayi sebanyak 33 dari 17.416 kelahiran hidup, sehingga didapatkan Angka Kematian Bayi (AKB) sebesar 2 per 1000 kelahiran hidup. Angka kematian dan kesakitan bayi masih tergolong tinggi. Salah satu upaya pelayanan kesehatan yang berkualitas dan terjangkau untuk membantu mengurangi angka kematian bayi adalah melalui stimulasi pijat bayi. Stimulasi ini diketahui cukup efektif, ekonomis dan aman untuk dilakukan oleh orang tua dalam memelihara kesehatan bayinya. Pijat bayi sangat dianjurkan untuk dilakukan oleh orang tua khususnya ibu, karena efek dari stimulasi ini adalah memberikan efek yang luar biasa pada perkembangan fisik, emosi, dan tumbuh kembang bayi Namun pada realitanya, tidak semua orang tua dapat melakukan pijat bayi kepada buah hatinya dan cenderung untuk membawa bayinya ke dukun pijat atau terapi pijat karena takut dan belum memiliki pengetahuan dan pengalaman dalam melakukan pijat bayi. Pendidikan Kesehatan merupakan salah satu upaya kegiatan yang dapat meningkatkan pengetahuan dan keterampilan dalam membantu ibu melakukan pijat bayi kepada ibu.

\section{METODE}

Variabel dalam penelitian ini adalah variabel independen yaitu Pendidikan Kesehatan tentang Pijat Bayi dan variable dependen yaitu Frekuensi ibu melakukan Pijat Bayi. Instrumen yang digunakan adalah checklist observasi dan penilaian observasi melakukan pijat bayi sesuai standar operasional prosedur (SOP). Responden akan diamati oleh peneliti mulai dari tahap persiapan sampai terminasi kegiatan, kemudian dilakukan follow up setelah 4 minggu.

Penelitian ini menggunakan penelitian Quasy Experimental dengan rancangan penelitian one group pre test dan post test, dengan pendekatan crossectional (Arikunto, 2013). Analisis data dilakukan dengan menggunakan teknik statistik deskriptif dan statistik inferensial. Statistik deskriptif untuk mendeskripsikan data penelitian yaitu statistik rata-rata, tabel distribusi persentase, tabel rata-rata cell, dan tabel silang. Statistik inferensial digunakan untuk menguji hipotesis. Uji signifikansi pengaruh tingkat pendidikan dan status kerja terhadap frekuensi pijat bayi secara simultan direncanakan menggunakan teknik statistik analisis varians 2-jalur namun distribusi data tidak memungkinkan sehingga analisis dilakukan secara parsial. Uji signifikansi pengaruh tingkat pendidikan terhadap frekuensi pijat bayi dilakukan menggunakan teknik statistik analisis varians 1-jalur dan uji signifikansi pengaruh status kerja terhadap frekuensi pijat bayi dilakukan menggunakan teknik statistik $t$-student sampel saling bebas.

Pengambilan sampel menggunakan tehnik purposive sampling yang memenuhi kriteria inklusi dan eksklusi, dengan cara accidental sampling yaitu pengambilan sampel dengan mengambil kasus atau responden yang kebetulan ada tersedia di suatu tempat sesuai dengan konteks penelitian. (Arikunto, 2013). Lokasi penelitian di lingkungan Rumah Sakit D kota Samarinda. 
HASIL

\section{Deskripsi Data}

\section{a. Latar Belakang Responden}

1) Umur Ibu dan Bayi

Responden yang menjadi penelitian ini sebanyak 30 orang yakni ibu-ibu yang memiliki bayi. Rata-rata umur mereka yaitu 29,56 tahun yang bervariasi mulai dari 23 tahun sampai dengan 39 tahun. Distribusi responden menurut pengelompokan umur memberikan petunjuk bahwa sebagian besar responden masih berpotensi untuk melahirkan atau menambah jumlah anak di masa yang akan datang, hal itu berdasarkan jumlah responden yang berumur 30 tahun ke bawah yaitu 66,7 persen sebagaimana disajikan dalam tabel 1.1.

Tabel 1.1. Distribusi Responden Menurut Umur

\begin{tabular}{cccc}
\hline $\begin{array}{c}\text { Gol. } \\
\text { Umur }\end{array}$ & Jumlah & $\boldsymbol{\%}$ & $\begin{array}{c}\text { \% } \\
\text { Kumulatif }\end{array}$ \\
\hline $23-25$ & 3 & 10,0 & 10,0 \\
$26-30$ & 17 & 56,7 & 66,7 \\
$31-35$ & 5 & 16,7 & 83,3 \\
$36-39$ & 5 & 16,7 & 100,0 \\
\hline Jumlah & $\mathbf{3 0}$ & $\mathbf{1 0 0}$ & \\
\hline
\end{tabular}

Tabel 1.2. Distribusi Responden Menurut Umur Bayinya

\begin{tabular}{cccc}
\hline $\begin{array}{c}\text { Umur } \\
\text { Bayi }\end{array}$ & Jumlah & \% & \% Kumulatif \\
\hline $3-6$ & 21 & 70 & 70 \\
$7-12$ & 9 & 30 & 100 \\
\hline Jumlah & $\mathbf{3 0}$ & $\mathbf{1 0 0}$ & \\
\hline
\end{tabular}

Rata-rata umur bayi para responden yaitu 5,7 bulan dan bervariasi mulai umur 3 bulan sampai dengan 12 bulan. Sebagian besar yakni 70,0 persen responden memiliki bayi yang berumur 6 bulan ke bawah sebagaimana disajikan dalam tabel 1.2. Distribusi persentase tersebut dan rata-rata umur bayi kurang dari 6 bulan, menunjukkan bahwa responden memiliki waktu merawat bayi relatif masih terbilang lama.

\section{2) Jumlah Anak}

Data jumlah anak para responden memiliki rata-rata 1,86 yang bervariasi mulai 1 orang sampai dengan 4 orang.

Tabel 1.3. Distribusi Responden Menurut Jumlah Anak

\begin{tabular}{cccc}
\hline $\begin{array}{c}\text { Jumlah } \\
\text { Anak }\end{array}$ & Jumlah & \% & \% Kumulatif \\
\hline 1 & 11 & 36,7 & 36,7 \\
2 & 13 & 43,3 & 80,0 \\
3 & 5 & 16,7 & 96,7 \\
4 & 1 & 3,3 & 100,0 \\
\hline Jumlah & $\mathbf{3 0}$ & $\mathbf{1 0 0 , 0}$ & \\
\hline
\end{tabular}

Terlihat bahwa responden yang baru memiliki anak 1 orang jumlahnya tidak kurang dari 35 persen dan yang memiliki anak 2 orang lebih dari 40 persen. Persentase tersebut dan besaran rata-rata jumlah anak 1,86 menguatkan asumsi sebelumnya bahwa sebagian besar responden masih berpotensi untuk melahirkan atau menambah jumlah anak di masa yang akan datang.

\section{b. Variabel Penelitian}

1) Tingkat Pendidikan

Tingkat pendidikan responden penelitian ini terbilang tinggi. Data penelitian menunjukkan bahwa tidak kurang dari 63 persen responden menyelesaikan pendidikan pada jenjang perguruan tinggi, bahkan 10 persen diantaranya bergelar magister, dan yang paling banyak adalah alumni DiplomaIII. Distribusi responden menurut tingkat pendidikan selengkapnya disajikan dengan tabel berikut.

Tabel 1.4. Distribusi Responden Menurut Tingkat Pendidikan

\begin{tabular}{cccc}
\hline $\begin{array}{c}\text { Tingkat } \\
\text { Pendidikan }\end{array}$ & Jumlah & $\%$ & $\begin{array}{c}\text { Persentase } \\
\text { Kumulatif }\end{array}$ \\
\hline S2 & 3 & 10,0 & 10,0 \\
S1 & 6 & 20,0 & 30,0 \\
D3 & 10 & 33,3 & 63,3 \\
SMA & 6 & 20,0 & 83,3 \\
SMP & 5 & 16,7 & 100,0 \\
\hline Jumlah & $\mathbf{3 0}$ & $\mathbf{1 0 0}$ & \\
\hline
\end{tabular}


1) Status Kerja

Responden yang tidak terjun sebagai angkatan kerja atau status IRT sebanyak 53,3 persen dan sebanyak 46,7 persen memiliki status bekerja. Responden yang bekerja tersebut semuanya bekerja pada sektor formal.

Tabel 1.5. Distribusi Responden

Menurut Status Kerja

\begin{tabular}{cccc}
\hline $\begin{array}{c}\text { Status } \\
\text { Kerja }\end{array}$ & Jumlah & \% & $\begin{array}{c}\text { \% } \\
\text { Kumulatif }\end{array}$ \\
\hline Tidak & 16 & 53,3 & 53,3 \\
Kerja & 14 & 46,7 & 100,0 \\
Kerja & & & \\
\hline Jumlah & $\mathbf{3 0}$ & $\mathbf{1 0 0 , 0}$ & \\
\hline
\end{tabular}

Tentang keterkaitan status kerja dengan tingkat pendidikan, dapat dijelaskan berdasarkan tabel berikut.

Tabel 1.6 Distribusi Responden Menurut Status Kerja Berdasarkan Tingkat Pendidikan

\begin{tabular}{cccc}
\hline \multirow{2}{*}{$\begin{array}{l}\text { Tingkat } \\
\text { Pendidikan }\end{array}$} & $\begin{array}{c}\text { Status Kerja } \\
\text { Tdk } \\
\text { Kerja }\end{array}$ & Kerja & Total \\
\hline S2 & $0(0,0)$ & $3(21,4)$ & $3(10,0)$ \\
S1 & $0(0,0)$ & $6(42,9)$ & $6(20,0)$ \\
D3 & $6(37,5)$ & $4(28,6)$ & $10(33,3)$ \\
SMA & $6(37,5)$ & $0(0,0)$ & $6(20,0)$ \\
SMP & $4(25,0)$ & $1(7,1)$ & $5(16,7)$ \\
\hline Jumlah & $\mathbf{1 6}$ & $\mathbf{1 4}$ & $\mathbf{3 0}$ \\
& $\mathbf{( 1 0 0 , 0 )}$ & $\mathbf{( 1 0 0 , 0 )}$ & $\mathbf{( 1 0 0 , 0 )}$ \\
\hline
\end{tabular}

Terlihat bahwa responden yang bekerja sebagian besar yaitu 92,9 persen alumni perguruan tinggi dan hanya 7,1 persen berpendidikan sekolah menengah. Sebaliknya pada kelompok responden yang tidak bekerja, sebagian besar yaitu 62,5 persen berpendidikan sekolah menengah dan hanya 37,5 persen alumni perguruan tinggi yaitu alumni DiplomaIII.

\section{2) Frekuensi Pijat Bayi}

Frekuensi responden melakukan pijat bayi dalam seminggu memiliki rata-rata 2,9 (hampir 3 kali) dengan variasi paling sedikit 1 kali dan paling banyak 6 kali. Pada tabel 1.7 terlihat bahwa 50 persen responden melakukan pijat bayi tidak lebih dari 2 kali seminggu.

Tabel 1.7. Distribusi Responden

Menurut Frekuensi Pijat Bayi

\begin{tabular}{cccc}
$\begin{array}{r}\text { Frekuensi } \\
\text { Pijat Bayi }\end{array}$ & Jumlah & $\boldsymbol{\%}$ & $\begin{array}{c}\text { \% } \\
\text { Kumulatif }\end{array}$ \\
\hline 1 & 1 & 3,3 & 3,3 \\
2 & 14 & 46,7 & 50,0 \\
3 & 10 & 33,3 & 83,3 \\
5 & 2 & 6,7 & 90,0 \\
6 & 3 & 10,0 & 100,0 \\
\hline Jumlah & $\mathbf{3 0}$ & $\mathbf{1 0 0 , 0}$ & \\
\hline
\end{tabular}

Kemungkinan adanya hubungan frekuensi melakukan pijat bayi dalam seminggu dengan tingkat pendidikan responden, dapat dijelaskan berdasarkan tabel 1.8. Terlihat bahwa tidak terjadi pola linier perubahan besaran rata-rata frekuensi pijat bayi dengan semakin tingginya tingkat pendidikan responden. Hal tersebut mengindikasikan bahwa antara tingkat pendidikan dengan frekuensi melakukan pijat bayi cenderung tidak ada hubungan.

Tabel 1.8. Rata-Rata Responden Melakukan Pijat Bayi Menurut Tingkat Pendidikan

\begin{tabular}{cc}
\hline $\begin{array}{c}\text { Tingkat } \\
\text { Pendidikan }\end{array}$ & $\begin{array}{c}\text { Rata-Rata Melakukan } \\
\text { Pijat Bayi }\end{array}$ \\
\hline S2 & 2,33 \\
S1 & 2,16 \\
D3 & 3,40 \\
SMA & 3,50 \\
SMP & 2,40 \\
\hline Total & $\mathbf{2 , 9 0}$ \\
\hline
\end{tabular}

Untuk variabel status kerja, tabel 1.9 memperlihatkan bahwa rata-rata frekuensi melakukan pijat bayi oleh responden yang tidak bekerja lebih tinggi 1,15 poin dibandingkan responden yang bekerja. Hal itu menunjukkan kecenderungan hubungan negatif antara keikutsertaan responden sebagai angkatan kerja dengan frekuensi melakukan pijat bayi. 
Tabel 1.9. Rata-Rata Responden Melakukan Pijat Bayi Menurut Status Kerja

\begin{tabular}{cc}
\hline Status Kerja & $\begin{array}{c}\text { Rata-Rata Melakukan } \\
\text { Pijat Bayi }\end{array}$ \\
\hline $\begin{array}{c}\text { Tidak Kerja } \\
\text { Kerja }\end{array}$ & 3,43 \\
& 2,28 \\
\hline Total & $\mathbf{2 , 9 0}$ \\
\hline
\end{tabular}

\section{Analisis Inferensial}

\section{a. Pengaruh Pendidikan Ibu Terhadap Frekuensi Pijat Bayi \\ Variabel tingkat pendidikan ibu} terdiri 5 kategori yaitu SMP, SMA, DIII, S-1, dan S-2, maka penyelidikan pengaruhnya terhadap frekuensi melakukan pijat bayi dilakukan dengan menggunakan teknik statistik Analisis. Varians Satu Jalur. Hipotesis statistik yang diajukan adalah :

$H_{0}: \mu_{1}=\mu_{2}=\mu_{3}=\mu_{4}=\mu_{5}$ (pendidikan tidak berpengaruh terhadap frekuensi pijat bayi) $H_{1}$ : Bukan $H_{0}$ (pendidikan tidak berpengaruh terhadap frekuensi pijat bayi)

Hasil perhitungan diperoleh nilai $F=1,482$ dengan probabilitas sebesar 0,238 . Karena nilai probabilitas lebih dari 5 persen maka $H_{0}$ diterima yang berarti bahwa tidak ada perbedaan ratarata frekuensi pijat bayi menurut tingkat pendidikan, dan disimpulkan bahwa pendidikan ibu tidak berpengaruh terhadap frekuensi melakukan pijat bayi.

\section{b. Pengaruh Status Kerja Ibu Terhadap Frekuensi Pijat Bayi}

Variabel Status Kerja Ibu terdiri 2 kategori yaitu Bekerja dan Tidak Bekerja, maka penyelidikan pengaruhnya terhadap frekuensi pijat bayi dilakukan dengan menggunakan teknik statistik $t$-student sampel saling bebas.
Hipotesis statistik yang diajukan adalah :

$$
H_{0}: \mu_{1}=\mu_{2}
$$

(status kerja tidak berpengaruh terhadap frekuensi pijat bayi)

$H_{1}:$ Bukan $H_{0}$
(status kerja berpengaruh terhadap
frekuensi pijat bayi)

Hasil perhitungan diperoleh nilai $t=2,680$ dengan probabilitas sebesar 0,14 . Karena nilai probabilitas kurang dari 5 persen maka $H_{0}$ ditolak yang berarti bahwa ada perbedaan rata-rata frekuensi pijat bayi menurut status kerja, dan disimpulkan bahwa status kerja berpengaruh terhadap frekuensi melakukan pijat bayi; bahwa ibu yang tidak bekerja lebih sering melakukan pijat bayi dibandingkan ibu yang bekerja.

\section{PEMBAHASAN}

Upaya menurunkan angka kesakitan dan kematian bayi bukan hanya tanggung jawab pemerintah, tetapi juga menuntut keterlibatan masyarakat khususnya keluarga. Salah satu perhatian terhadap kesehatan bayi adalah melakukan pemijatan pada bayi, yang tidak hanya berdampak positif terhadap kesehatan bayi tetapi juga semakin mempererat hubungan bathin antara ibu dan bayi. Sayangnya tidak semua ibu dapat melakukan pemijatan kepada buah hatinya, bahkan banyak diantaranya yang cenderung mempercayakan pemijatan bayi kepada dukun pijat atau terapi pijat. Hal tersebut menjadi alasan untuk melakukan suatu penelitian tentang frekuensi ibu melakukan pijat bayi yang diassosiasikan dengan variabel tingkat pendidikan ibu dan dengan memperhatikan keterlibatan ibu sebagai angkatan kerja (variabel status kerja ibu).

Tingkat pendidikan seorang ibu diasumsikan berkorelasi positif dengan kesadaran akan pentingnya 
menjaga/memperhatikan masalah kesehatan khususnya kesehatan bayi dan karena itu diduga bahwa semakin tinggi tingkat pendidikan ibu maka semakin sering pula melakukan pemijatan kepada bayinya. Namun analisis data penelitian ini tidak mendukung asumsi teoritis tersebut. Analisis varians memberikan hasil bahwa rata-rata frekuensi pijat bayi antara kelima kategori tingkat pendidikan tidak berbeda secara signifikan, sehingga disimpulkan bahwa tingkat pendidikan ibu tidak berpengaruh terhadap frekuensi melakukan pijat bayi. Pada bagian deskripsi data, disajikan bahwa tidak terjadi pola linier perubahan besaran rata-rata frekuensi pijat bayi dengan semakin tingginya tingkat pendidikan responden. Bahkan nyaris berkorelasi negatif, bahwa rata-rata frekuensi pijat bayi pada kelompok responden berpendidikan sarjana dan magister malah justru lebih rendah dibandingkan kelompok tingkat pendidikan lainnya.

Analisis assosiatif antara variabel status kerja dengan frekuensi pijat bayi ditemukan kenyataan bahwa keterlibatan ibu sebagai angkatan kerja berpengaruh negatif terhadap frekuensi melakukan pijat bayi. Analisis statistik $t$-student sampel saling bebas untuk uji perbedaan rata-rata memberikan kesimpulan bahwa ibu yang tidak bekerja lebih sering melakukan pijat bayi dibandingkan ibu yang bekerja dengan perbedaan 1,15 poin.

Adanya pengaruh negatif variabel status kerja terhadap pijat bayi, bahwa ibu yang tidak bekerja lebih sering melakukan pijat bayi dibandingkan ibu yang bekerja, merupakan dasar untuk menjelaskan perihal tingkat pendidikan ibu tidak berpengaruh terhadap frekuensi melakukan pijat bayi. Pada bagian deskripsi data disajikan bahwa responden yang terjun sebagai angkatan kerja sebagian besar yaitu 92,9 persen adalah alumni perguruan tinggi dan hanya 7,1 persen berpendidikan sekolah menengah. Jadi, pengaruh pendidikan terhadap frekuensi pijat bayi yang tidak signifikan oleh karena ibu-ibu yang berpendidikan tinggi sebagian besar terjun sebagai angkatan kerja.

Melakukan pemijatan kepada bayi, selain membangun ikatan bathin antara ibu dan bayi, juga sangat bermanfaat bagi kesehatan bayi. Pemijatan bayi akan melancarkan peredaran darah dan meningkatkan kadar hormon oksitosin, yang membuat bayi lebih rileks, senang, tidak rewel, dan tidak mudah gelisah yang mana kondisi tersebut akan membuat bayi lebih mudah tidur lelap/pulas sehingga dapat terhindar dari bangun/menangis tengah malam. Stimulan berupa sentuhan ibu yang lembut dan berirama ketika melakukan pijat bayi, akan merangsang aktivitas saraf-saraf bayi sehingga berbagai saraf tersebut akan lebih cepat berkembang. Stimulan tersebut juga akan menghasilkan mielin, yaitu zat pada otak yang bertanggung jawab untuk mengatur impuls saraf yang berkaitan dengan kemampuan motorik dan sensoris. Selain itu, otototot bayi juga akan jadi lebih fleksibel dan kuat. Penjelasan tersebut memberikan konklusi bahwa pijat bayi tidak hanya bermanfaat terhadap kondisi fisik bayi tetapi juga terhadap perkembangan mental dalam jangka panjang.

Oleh karena pemijatan bayi sangat bermanfaat, maka kepada para ibu khususnya yang menjadi responden penelitian ini agar melakukannya secara intensif, yang mana idealnya dilakukan setiap hari. Deskripsi data hasil penelitian ini mengindikasikan bahwa responden penelitian ini belum intensif melakukan pemijatan bayi; 50 persen melakukannya tidak lebih dari 2 kali dalam seminggu, dan hanya 10 persen yang melakukannya hampir setiap hari. Tentu saja hal tersebut menuntut 
perhatian berupa pemberian
informasi/penyuluhan yang tepat
sasaran.

Sebagai implikasi dari temuan penelitian ini, penyuluhan tentang pentingnya melakukan pijat bayi hendaknya dilakukan tanpa memandang pendidikan ibu, tetapi lebih diprioritaskan kepada ibu-ibu yang terjun sebagai angkatan kerja. Kepada ibu-ibu yang bekerja perlu diberi kesadaran tentang manfaat pijat bayi terhadap kesehatan bayi terutama kondisi fisik dan mental anaknya di masa depan. Kalau selama ini mereka melakukan pijat bayi hanya pada hari libur yaitu sabtu dan minggu, hendaknya mereka melakukannya juga di hari lain sepulang dari bekerja, kalaupun terpaksa setidak-tidaknya menyerahkan kepada anggota keluarga lain seperti ayah/suami atau neneknya yang sudah terlatih melakukan pijat bayi.

Pemberian informasi tentang manfaat pijat bayi hendaknya dibarengi dengan pelatihan agar para ibu dapat melakukan pijat bayi dengan teknik yang benar. Menyelenggarakan pelatihan atau pendidikan kesehatan tentu saja butuh waktu dan tenaga serta anggaran, sehingga diperlukan keterlibatan berbagai pihak dalam rangka memasyarakatkan pijat bayi, baik pemerintah maupun pihak swasta dan terutama dukungan keluarga.

Ibu-ibu yang menjadi responden penelitian sebagian besar yaitu 70 persen memiliki bayi berumur tidak lebih 6 bulan yang berarti masih cukup lama merawat bayinya. Sebagian besar juga masih berpotensi melahirkan atau menambah jumlah anak, hal ini berdasarkan deskripsi data bahwa responden yang baru memiliki anak 1 orang jumlahnya tidak kurang dari 35 persen dan yang memiliki anak 2 orang lebih dari 40 persen. Selain itu, responden yang berumur 30 tahun ke bawah jumlahnya cukup banyak yakni
66,7 persen. Sehingga, upaya meningkatkan kesadaran tentang manfaat dan pentingnya pijat bayi, tidak hanya berdampak positif terhadap kesehatan bayinya sekarang tetapi juga terhadap anak berikutnya. Dan, pada gilirannya upaya tersebut diharapkan dapat mengurangi angka kesakitan dan kematian bayi baik pada skala regional maupun skala nasional.

\section{KESIMPULAN DAN SARAN}

\section{Kesimpulan}

Berdasarkan hasil analisis data, kesimpulan penelitian ini adalah : Tidak ada perbedaan rata-rata frekuensi melakukan pijat bayi menurut tingkat pendidikan ibu, dengan kata lain bahwa tingkat pendidikan tidak berpengaruh terhadap frekuensi ibu melakukan pijat bayi. Hal tersebut karena ibu-ibu yang tidak bekerja memiliki rata-rata frekuensi melakukan pijat bayi yang lebih tinggi dibandingkan ibu-ibu yang bekerja, sementara ibu-ibu yang terjun sebagai angkatan kerja tersebut sebagian besar adalah ibu-ibu berpendidikan tinggi.

\section{Saran}

Sebagai implikasi dari hasil penelitian ini, maka dikemukakan saran sebagai berikut :

1. Pemijatan bayi sangat bermanfaat bagi kesehatan bayi guna menekan angka kesakitan dan kematian bayi, oleh karena itu agar penyuluhan/pemberian informasi dan pelatihan kepada masyarakat luas hendaknya digalakkan. Upaya sosialisasi tersebut agar didukung oleh pemerintah, pihak swasta, dan pihak keluarga.

2. Penyuluhan/pemberian informasi dan pelatihan pijat bayi agar dilakukan tanpa memandang pendidikan ibu, tetapi diprioritaskan kepada ibu-ibu yang terjun sebagai angkatan kerja. 
3. Ibu-ibu yang terjun sebagai angkatan kerja dan tidak punya waktu untuk melakukan pijat bayi setiap hari, agar mempercayakan pemijatan bayinya kepada anggota keluarga lain atau pengasuh bayi yang terlatih melakukan pijat bayi.

4. Dalam rangka menekan angka kesakitan dan kematian bayi, kepada peneliti lain agar melakukan penelitian sejenis untuk menyempurnakan hasil penelitian ini.

\section{DAFTAR PUSTAKA}

Arikunto, S. (2013). Prosedur Penelitian: Suatu Pendekatan Praktik. Jakarta: Rineka Cipta.

Databoks. (2016). Meski menurun, angka kematian bayi di Indonesia masih tinggi. Diakses dari: https://databoks.katadata.co.id/datapu blish/2016/11/25/meski-menurunangka-kematian-bayi-di-indonesiamasih-tinggi\#.Tanggal 25 september 2018. Jam 17.00 WITA.

Iryanti, Rahma. (2015). Tingkat Partisipasi Angkatan Kerja Perempuan Harus Ditingkatkan. Diakses 10 juli 2019 dari Jurnal Perempuan Edisi Juli 2015: https://www.jurnalperempuan.org/war ta-feminis/rahma-iryanti-tingkatpartisipasi-angkatan-kerjaperempuan-harus-ditingkatkan

Mother \& Baby. (2014). Bayi Butuh Pijatan Ibu. Diambil dari: https://www.motherandbaby.co.id/arti cle/2014/1/8/1478/Bayi-ButuhPijatan-Ibu. Tanggal 25 september, 2018. Jam 18.00

Dinas Kesehatan Kota Samarinda. (2016). Profil Kesehatan Kota Samarinda. Bakti Husada: Samarinda

Maulana, H. (2009). Promosi Kesehatan. Jakarta: EGC
Prasetyono, D. S. (2013). Buku Pintar Pijat Bayi. Jogjakarta: Buku Biru.

Rizki, L. K. (2017). Efektivitas pijat bayi terhadap perkembangan motorik pada bayi usia 8-28 hari. Maternal and Neonatal Health Journal vol. 1, No. 2. 76-80.

Roesli, U. (2013). Pedoman pijat bayi (bayi usia 3 bulan ke atas). Jakarta: Trubus Agriwidya.

Seidel, R. J., Perencevich, K. C \& Kett, A. L. (2005). From principles of learning to strategies for instruction: Empirically based ingredients to guide instructional development. USA: Springer

Thomas, T. (2017). Teaching is an art. Yogyakarta: CV Budi Wijaya.

Tjaja, Ratna P. (2000). Wanita Bekerja dan Implikasi Sosial. diakses tanggal 10 juli 2019 dari Jurnal Bappenas https://www.bappenas.go.id/files/65 $\underline{13 / 5228 / 3053 / \text { ratna }}$

Tomei, L. A (2005). Taxonomy for the Technology Domain. USA: Information Science Publishing

Walker, Peter. (2011). Panduan Lengkap Pijat Bayi. Jakarta: Puspa Swara.

Wong, Donna L, (2003). Pedoman Klinis Keperawatan Pediatrik, Edisi 4. Jakarta: EGC. 